\title{
Layered Double Hydroxide/C (C=Humic Acid;Hydrochar) As Adsorbents of $\mathrm{Cr}(\mathrm{VI})$
}

\author{
Patimah Mega Syah Bahar Nur Siregar', Alfan Wijaya', Amri ${ }^{3}$, Juliana Putri Nduru ${ }^{3}$, Nurlisa Hidayati ${ }^{2}$, Aldes Lesbani ${ }^{2,3}$, Risfidian \\ Mohadi $^{2 *}$ \\ ${ }^{1}$ Magister Programme Graduate School of Mathematics and Natural Sciences, Sriwijaya University, Palembang 30139, Indonesia \\ ${ }^{2}$ Graduate School of Faculty Mathematics and Natural Sciences, Sriwijaya University, Palembang 30139, Indonesia \\ ${ }^{3}$ Research Center of Inorganic Materials and Complexes, Faculty of Mathematics and Natural Sciences, Sriwijaya University, Palembang 30139, Indonesia \\ *Corresponding author: risfidian.mohadi@unsri.ac.id
}

\begin{abstract} $75.029 \%$.

Keywords

Composite, Layered Double Hydroxide, Humic Acid, Hydrochar, Adsorption
\end{abstract}

Layered double hydroxide (LDH) is known as a layered material that can be used as an adsorbent to remove pollutants from aqueous solutions. The use of layered double hydroxide as an adsorbent is not very effective due to its structure which is easily damaged so that it cannot be reused and its small surface area which results in a small adsorption capacity. This can be overcome by developing layered double hydroxide into a composite material. Modification of layered double hydroxide is done by using supporting materials in the form of humic acid and hydrochar. In this study the adsorbent was applied in the removal of $\mathrm{Cr}(\mathrm{VI}) \mathrm{metal}$ from aqueous solutions. The layered double hydroxide modification process was successfully carried out as seen from the XRD, FTIR, and BET analysis. XRD analysis shows the peaks that appear in $\mathrm{Mg} / \mathrm{Al}-\mathrm{AH}$ and $\mathrm{Mg} / \mathrm{Al}-\mathrm{HC}$ are peaks composed of their constituent materials, namely $\mathrm{Mg} / \mathrm{Al} \mathrm{LDH}$, humic acid, and hydrochar. The vibrations that appear in $\mathrm{Mg} / \mathrm{Al}-\mathrm{AH}$ and $\mathrm{Mg} / \mathrm{Al}-\mathrm{HC}$ are vibrations originating from $\mathrm{Mg} / \mathrm{Al}$, humic acid, and hydrochar. The layered double hydroxide material composited with humic acid showed a surface area from $2.155 \mathrm{~m}^{2} / \mathrm{g}$ to $3.337 \mathrm{~m}^{2} / \mathrm{g}$. The layered double hydroxide material composited with hydrochar showed a larger surface area than the Mg/Al LDH base material. The surface area increased 37 times, from $2.155 \mathrm{~m}^{2} / \mathrm{g}$ to $74.207 \mathrm{~m}^{2} / \mathrm{g}$. The Mg/Al-AH composite showed the first adsorption ability of $89.064 \%$ and there was no significant decrease in the next cycle. The $\mathrm{Mg} / \mathrm{Al}-\mathrm{HC}$ composite showed adsorption ability in the first cycle which reached $97.079 \%$, the ability to survive up to the fifth cycle with a final ability of

Received: 18 September 2021, Accepted: 03 December 2021

https://doi.org/10.26554/sti.2022.7.1.41-48

\section{INTRODUCTION}

The chemical, paper, and pharmaceutical industries are considered to be the main sources of heavy metal pollution in the environment. Pollution can cause problems in human health and ecosystems (Ahmadpoor et al., 2019). The problem of heavy metal pollution has high toxicity and cannot be decomposed naturally (Chen et al., 2019). Thus, a method is needed to reduce metal content in waste. Various methods have been carried out to reduce heavy metal levels from waste such as oxidation (El-Sherif et al., 2013), coagulation (Huang et al., 2019), ion exchange (Shrestha, 2018), and adsorption (Shrestha, 2018). Among these methods, adsorption is a method that has high efficiency and low cost and flexibility and simple operation (Gadekar and Ahammed, 2016). Raw materials that can be used as adsorbents in the $\mathrm{Cr}(\mathrm{VI})$ adsorption process include activated carbon (Li et al., 2020b), chitosan (Hasan et al., 2020), graphene (Hosseinzadeh and Ramin,
2018), biochar (Zubair et al., 2021), banana peels (Shrestha, 2018), and layered double hydroxide (Hatami et al., 2018).

Layered double hydroxide (LDH) known as hydrotalcite clay or anionic clay, has attracted attention in various fields such as catalysts, hydrogenation, oxidation, ion exchange, and adsorption (Hu et al., 2020). LDH is an efficient material to absorb/remove heavy metals from aqueous solutions (Rahmanian et al., 2018). LDH is a layered material with a layer such as positively charged brucite which has the general formula $\left.\left[\mathrm{M}^{2+}{ }_{1-x} \mathrm{M}^{3+}{ }_{x}(\mathrm{OH})_{2}\right]^{x+}\left(\mathrm{A}^{n-}\right)_{x / n} \cdot \mathrm{mH}_{2} \mathrm{O}\right]$ where $\mathrm{M}^{2+}$ and $\mathrm{M}^{3+}$ denote metal ions located on the sheet the positively charged octahedral (Marques et al., 2020). $\mathbf{M}^{2+}$ is a divalent metal ion and $\mathrm{M}^{3+}$ is a trivalent metal ion. $\mathrm{A}^{n-}$ is an interlayer anion that can be exchanged to neutralize positive charges, $x$ ranges from 0.17 to 0.33 and $x$ is the molar ratio (Mahjoubi et al., 2017).

The characteristics of LDH have flexible properties that are easy to modify and have interlayer anions that are easily 
exchanged but the stability of the structure is poor. LDH can be peeled off during the application process so that it can be reused very rarely and the LDH structure is more stable (Siregar et al., 2021). Therefore, it is necessary to improve the layered double hydroxide structure in order to strengthen the structure by inserting the support material. Supporting materials that can be used include biochar (Bolbol et al., 2019), hydrochar (Zhang et al., 2014), graphene (Siregar et al., 2021), chitosan (Saheed et al., 2020), and humic acid (Li et al., 2020a). The supporting material has active sites such as $\mathrm{OH}, \mathrm{COOH}, \mathrm{NH}_{2}$ so that it has the potential as a supporting material in the modification process.

Lee et al. (2019) in their research used Mg/Al-biochar for phosphate adsorption with an adsorption capacity of 70.75 $\mathrm{mg} / \mathrm{g}$. Research conducted by Zhang et al. (2020) using Mg/Al intercalated diethyldithiocarbamate as a $\mathrm{Cr}(\mathrm{VI})$ adsorbent resulted in an adsorption capacity of $52.00 \mathrm{mg} / \mathrm{g}$. Another layered double hydroxide use is $\mathrm{Cu} / \mathrm{Al}$ modified using biochar from rice husk with increased adsorption capacity from 22.272 $\mathrm{mg} / \mathrm{g}$ to $384.615 \mathrm{mg} / \mathrm{g}$ (Palapa et al., 2021).

In this study, the synthesis material of $\mathrm{Mg} / \mathrm{Al}-\mathrm{AH}$ and $\mathrm{Mg} / \mathrm{Al}-\mathrm{HC}$ from humic acid and hydrochar from Lansium domesticum peel was used to adsorb $\mathrm{Cr}(\mathrm{VI})$ metal. The effect of concentration variation and temperature variation of adsorption and desorption studies were tested using several solvents which aimed to determine the solvent with optimum $\mathrm{Cr}(\mathrm{VI})$ desorption conditions and the regeneration study was carried out in five cycles.

\section{EXPERIMENTAL SECTION}

\subsection{Materials and Method}

The chemicals used in this experiment $\mathrm{Mg}\left(\mathrm{NO}_{3}\right)_{2} \cdot 6 \mathrm{H}_{2} \mathrm{O}$ (Mer ck, $256.41 \mathrm{~g} / \mathrm{mol}), \mathrm{Al}\left(\mathrm{NO}_{3}\right)_{2} .9 \mathrm{H}_{2} \mathrm{O}$ (Merck, $375.13 \mathrm{~g} / \mathrm{mol}$ ), $\mathrm{NaOH}$ (Merck, $40.00 \mathrm{~g} / \mathrm{mol}$ ), $\mathrm{HCl} 37 \%$ by MallinckrodtAR, $\mathrm{C}_{2} \mathrm{H}_{5} \mathrm{OH}$ (Avantor, 99\%), the humic acid by Merck extracted from the peat soil as shown in Figure 1, the hydrochar source was made from Lansium domesticum peel. Water was obtained using Purite water purification system from the Research Center of Inorganic Materials and Complexes. The material characterization was performed using XRD Rigaku Miniflex-6000. FTIR analysis was conducted using Shimadzu FTIR Prestige21 by the $\mathrm{KBr}$ method and was scanned at $400-4000 \mathrm{~cm}^{-1}$. Adsorption-desorption of $\mathrm{N}_{2}$ Analysis was measured using Quantachrome Micrometic ASAP. The concentration of the dye was analyzed using spectrophotometer UV-Visible Biobase BK-UV 1800PG.

\subsection{Preparation of $\mathrm{Mg} / \mathrm{Al} \mathrm{LDH}$ (Chen et al., 2017)}

$\mathrm{Mg}\left(\mathrm{NO}_{3}\right)_{2} \cdot 6 \mathrm{H}_{2} \mathrm{O}$ and $\mathrm{Al}\left(\mathrm{NO}_{3}\right)_{2} \cdot 9 \mathrm{H}_{2} \mathrm{O}$ at $\mathrm{Mg}^{2+} / \mathrm{Al}^{3+}$ with molar ratio of $3: 1$ were weight and dissolved in purification water (called $\mathrm{Mg} / \mathrm{Al}$ solution). The $\mathrm{NaOH}$ added slowly into $\mathrm{Mg} / \mathrm{Al}$ solution until $\mathrm{pH}$ value achieved to 10 . After the addition was complete, the mixture was stirred for 1 hour, followed by increasing the temperature at $65^{\circ} \mathrm{C}$ for 6 hours. The prod-

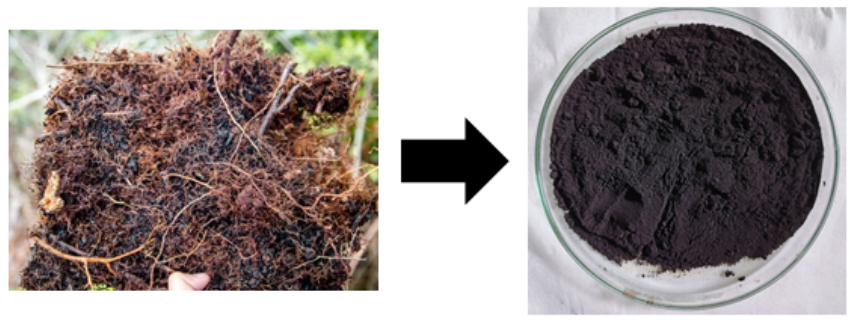

Figure 1. Humic Acid Extraction from Peat Soil

uct obtained is then filtered, washed until neutral and dried. Then, the material obtained is called $\mathrm{Mg} / \mathrm{Al}-\mathrm{LDH}$.

\subsection{Preparation of Hydrochar from Lansium Domesticum Peel by Hydrothermal Carbonization Method}

The preparation of the hydrochar material was carried out using $2.5 \mathrm{~g}$ of mashed Lansium domesticum peel as shown in Figure 2 and then put into a hydrothermal stainless-steal autoclave and added $50 \mathrm{~mL}$ of distilled water. Then put in the oven at $200^{\circ} \mathrm{C}$ for 12 hours. Then the obtained material is cooled and dried in an oven at a temperature of $100^{\circ} \mathrm{C}$.

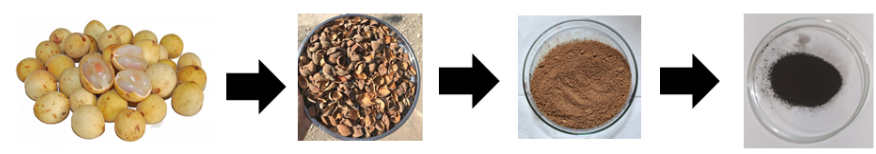

Figure 2. Preparation of Hydrochar from Lansium Domesticum Peel by Hydrothermal

\subsection{Preparation of $\mathrm{Mg} / \mathrm{Al}-\mathrm{AH}$ (Rahmadan et al., 2021)}

The preparation of $\mathrm{Mg} / \mathrm{Al}-\mathrm{AH}$ material is the same as the preparation of $\mathrm{Mg} / \mathrm{Al}-\mathrm{HC}$ using the coprecipitation method with the following procedure $30 \mathrm{~mL}$ of $\mathrm{Mg}\left(\mathrm{NO}_{3}\right)_{2} \cdot 6 \mathrm{H}_{2} \mathrm{O}$ $0.75 \mathrm{M}$ mixed with $30 \mathrm{~mL}$ of $\mathrm{Al}\left(\mathrm{NO}_{3}\right)_{2} .9 \mathrm{H}_{2} \mathrm{O} 0.25 \mathrm{M}$. Then $\mathrm{NaOH} 2 \mathrm{M}$ is added dropwise drops to $\mathrm{pH} 10$ and added 3 $\mathrm{g}$ of humic acid powder. The suspension was stirred at $80^{\circ} \mathrm{C}$ for 3 days. The product obtained is then filtered, washed until neutral and dried.

\subsection{Preparation of $\mathrm{Mg} / \mathrm{Al}-\mathrm{HC}$ (Normah et al., 2021)}

The $\mathrm{Mg} / \mathrm{Al}-\mathrm{HC}$ material was prepared using the coprecipitation method. As much as $30 \mathrm{~mL} \mathrm{Mg}\left(\mathrm{NO}_{3}\right)_{2} \cdot 6 \mathrm{H}_{2} \mathrm{O} 0.75 \mathrm{M}$ mixed with $30 \mathrm{~mL} \mathrm{Al}\left(\mathrm{NO}_{3}\right)_{2} .9 \mathrm{H}_{2} \mathrm{O} 0.25 \mathrm{M}$. then, $\mathrm{NaOH}$ was added dropwi to reaced $\mathrm{pH} 10$. Afterwards, as much as $3 \mathrm{~g}$ of hydrochar of Lansium domesticum peel was added to the mixture. The mixture Was stirred at a temperature of $80^{\circ} \mathrm{C}$ for 3 days. The product obtained is then filtered, washed until neutral and dried.

\subsection{Adsorption Process}

Isotherms and thermodynamic parameters are determined by concentration variation of $(50,60,70,80,90$, dan 100$) \mathrm{mg} / \mathrm{L}$ 
as much as $20 \mathrm{~mL}$, added $0.02 \mathrm{~g}$ of adsorbent and temperature variations at $30-60^{\circ} \mathrm{C}$. The concentration of $\mathrm{Cr}(\mathrm{VI})$ was analyzed after complexing using diphenylcarbazide at a wavelength of $543 \mathrm{~nm}$.

\subsection{Regeneration}

As much as $5 \mathrm{~g}$ of adsorbent was put in $50 \mathrm{~mL}$ of $100 \mathrm{mg} / \mathrm{L}$ $\mathrm{Cr}(\mathrm{VI})$ and then stirred for 2 hours. After that, the centrifugation process is carried out to separate the adsoben and the adsorbate residue. The solution was measured using a UV-Vis spectrophotometer after being complexed with diphenylcarbazide and the adsorbent was dried for desorption using water. The regeneration process is carried out by the adsorption-desorption process repeatedly in 5 cycles.

\section{RESULTS AND DISCUSSION}

Figure 3 shows the XRD pattern of each adsorbent. Figure 3(a) is an XRD pattern of $\mathrm{Mg} / \mathrm{Al}$ showing the appearance of a typical layered double hydroxide peak at $2 \theta$ angles $11.47^{\circ}(003)$, $22.86^{\circ}(006), 61.62^{\circ}(113), 65.50^{\circ}(116)$ according to JCPDS data No. 22-700 where the $\mathrm{Mg} / \mathrm{Al}$ diffraction pattern appears at $11.8^{\circ}(003), 23.6^{\circ}(006), 62.3^{\circ}(113)$ and $66.3^{\circ}(116)$. Research conducted by Chen et al. (2017) said that the diffraction peak around an angle of $11^{\circ}(003)$ with high intensity in $\mathrm{Mg} / \mathrm{Al}$ indicated the success of the synthesis of LDH materials.

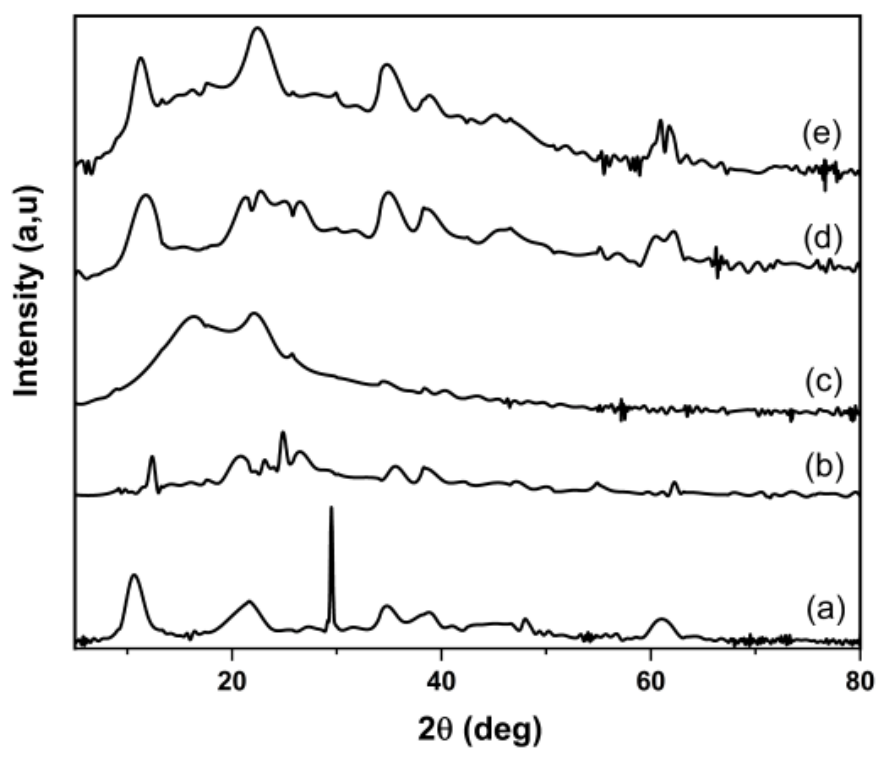

Figure 3. XRD Powder Patterns of Mg/Al LDH (a), AH (b), $\mathrm{HC}$ (c), Mg/Al-AH (d), and Mg/Al-HC (e)

Then the $\mathrm{Mg} / \mathrm{Al} \mathrm{LDH}$ material was modified using humic acid and hydrochar to form a composite. The modification process aims to obtain materials that have a larger surface area so that the adsorption capacity increases and the material structure is more stable so that it can be used repeatedly. The humic acid used was derived by Merck, and hydrochar obtained from the carbonization process of Lansium domesticum peel using the hydrothermal method. The obtained humic acid and hydrochar were characterized using XRD analysis.

Figure 3(b) shows the XRD pattern of humic acid. The XRD pattern of humic acid shows that diffraction peaks appear at angles of $20.01^{\circ}(006), 24.88^{\circ}(006)$ and $26.4^{\circ}(006)$. According to Zhang et al. (2018) strong diffraction peaks that appear at angles of about $21^{\circ}, 26.7^{\circ}, 31.48^{\circ}$ indicate the presence of large amounts of carbon contained in humic acid and has a fairly high crystallinity. The XRD pattern of the hydrochar shown in Figure 3(c) shows that peaks appear at an angle of $2 \theta$, namely $16^{\circ}(003)$ and $22.47^{\circ}(006)$. The diffraction peak of hydrochar at an angle of $16^{\circ}(003)$ has a lower intensity than the peak at an angle of $22.47^{\circ}(006)$ indicating of cellulose.

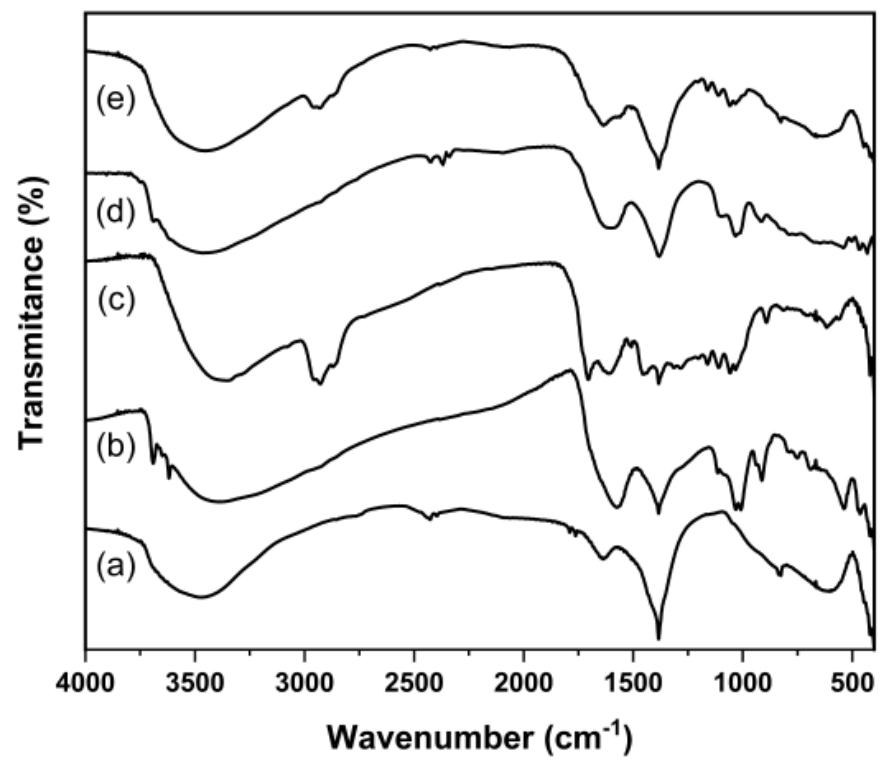

Figure 4. FTIR Spectrum of $\mathrm{Mg} / \mathrm{Al} \mathrm{LDH}(\mathrm{a}), \mathrm{AH}(\mathrm{b}), \mathrm{HC}$ (c), $\mathrm{Mg} / \mathrm{Al}-\mathrm{AH}$ (d), and $\mathrm{Mg} / \mathrm{Al}-\mathrm{HC}$ (e)

The $\mathrm{Mg} / \mathrm{Al}-\mathrm{AH}$ diffraction peaks are shown in Figure 3(d). Figure $3(\mathrm{~d})$ shows peaks appearing at the diffraction angles of $11.65^{\circ}(003), 21^{\circ}(006), 24^{\circ}(006), 31.05^{\circ}(012), 39.2^{\circ}(015)$ and $61.5^{\circ}(110)$. The diffraction peaks that appear at angles of $11.65^{\circ}$ and $61.5^{\circ}$ are characteristic of $\mathrm{Mg} / \mathrm{Al} \mathrm{LDH}$ which indicates a layered structure, while the diffraction peaks that appear at angles of about $21^{\circ}(006), 26^{\circ}(006)$ and $31.05^{\circ}(012)$ are characteristics of humic acid materials that have a large amount of carbon content tall one. This indicates that the preparation of $\mathrm{Mg} / \mathrm{Al}-\mathrm{AH}$ composite was successful. Figure 3(e) shows the XRD pattern of $\mathrm{Mg} / \mathrm{Al}-\mathrm{HC}$ with diffraction angles at $11.22^{\circ}(003), 11.6^{\circ}(003)$, and $61^{\circ}(110)$. The peak that appears is the peak of the base material in the form of $\mathrm{Mg} / \mathrm{Al}$ and the supporting material in the form of hydrochar. This is in accordance with the notion of composites, namely materials obtained from a combination of two or more materials with different characteristics, in order to obtain better characteristics 


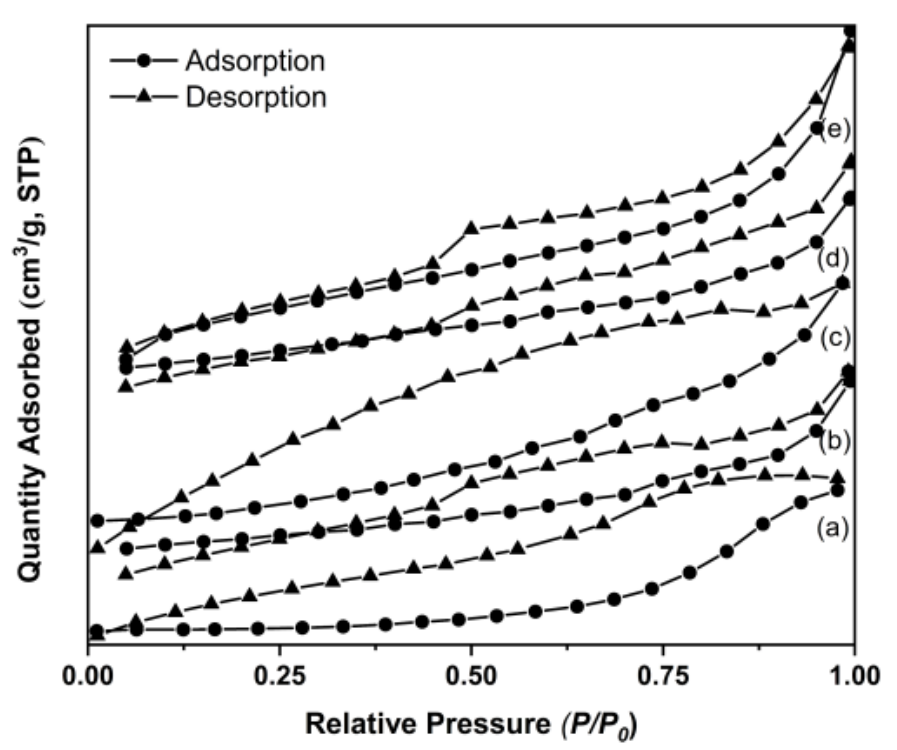

Figure 5. BET Profile of $\mathrm{Mg} / \mathrm{Al} \mathrm{LDH} \mathrm{(a),} \mathrm{AH}$ (b), $\mathrm{HC}$ (c), $\mathrm{Mg} / \mathrm{Al}-\mathrm{AH}$ (d), and $\mathrm{Mg} / \mathrm{Al}-\mathrm{HC}$ (e)

than the constituent materials.

Figure 4 shows the spectra of each material. Figure 4(a) is a spectrum of $\mathrm{Mg} / \mathrm{Al} \mathrm{LDH}$ where a vibration peak appears at a wave number of $3500 \mathrm{~cm}^{-1}$ which indicates -OH vibrations from water molecules, and vibrations at $1635 \mathrm{~cm}^{-1}$ which indicate stretching vibrations from -OH. There is also a vibration at $1381 \mathrm{~cm}^{-1}$ which indicates the presence of an N-O group derived from nitrate. The small peak that appears at the wave number of $748 \mathrm{~cm}^{-1}$ is the $\mathrm{M}-\mathrm{O}$ vibration in the form of $\mathrm{Mg}-\mathrm{O}$ and $\mathrm{Al}-\mathrm{O}$ (Zhang et al., 2018). Figure 4(b) shows the FTIR spectrum of humic acid. The wide vibrational peak at the wave number $3300-3500 \mathrm{~cm}^{-1}$ indicates the presence of an $-\mathrm{OH}$ group. The peak of the vibration at the wave number $1530-1570 \mathrm{~cm}^{-1}$ indicates the presence of an aromatic $\mathrm{C}=\mathrm{C}$ stretching vibration. The vibration peaks produced from the wave number $1375-1390 \mathrm{~cm}^{-1}$ indicate the presence of $\mathrm{C}-\mathrm{H}$ bending vibrations and $\mathrm{C}-\mathrm{H}$ deformation of the aromatic $\mathrm{CH}_{2}$ and $\mathrm{CH}_{3}$ groups, while the peak vibrations at the wave number $1010-1050 \mathrm{~cm}^{-1}$ indicate the presence of $\mathrm{C}-\mathrm{O}$ stretching vibrations of the polysaccharides. According to Helal et al. (2011) the FTIR spectrum of humic acids which shows the dominance of the $\mathrm{OH}, \mathrm{COOH}$ and $\mathrm{COO}$ - groups is a characteristic of humic soils. Hydrochar spectrum appears at wave numbers $3425 \mathrm{~cm}^{-1}$ and $1625 \mathrm{~cm}^{-1}$ which is the -OH vibration of the water molecule and the strain vibration of $-\mathrm{OH}$. In addition, a vibration appears at wave number $2931 \mathrm{~cm}^{-1}$ which is a -CH stretching vibration of the lignin contained in the hydrochar as shown in Figure 4(c).

The $\mathrm{Mg} / \mathrm{Al}-\mathrm{AH}$ spectrum is shown in Figure 4(d), peak appears at a wave number of $1381.03 \mathrm{~cm}^{-1}$ which indicates the presence of nitrate bonding vibrations, thus illustrating the presence of nitrate anions in $\mathrm{Mg} / \mathrm{Al}$ and a peak at a wave number of $432.05 \mathrm{~cm}^{-1}$ and $540.07 \mathrm{~cm}^{-1}$ which indicate the buckling vibrations of $\mathrm{Mg}-\mathrm{O}$ and $\mathrm{Al}-\mathrm{O}$. Another vibration that appears is at wave number $3464.15 \mathrm{~cm}^{-1}$ which is marked by a wide peak which indicates the $\mathrm{O}-\mathrm{H}$ stretching vibration. In addition, there is a vibration peak at wave number 1604.77 $\mathrm{cm}^{-1}$ which indicates the presence of a $\mathrm{C}=\mathrm{C}$ group from the aromatic ring or conjugated $\mathrm{H}$ from the $\mathrm{C}=\mathrm{O}$ group from the carbonyl group (carboxylate or ketone). The FT-IR spectrum of $\mathrm{Mg} / \mathrm{Al}-\mathrm{HC}$ shown in Figure 4(e) shows that there is a vibration resembling $\mathrm{Mg} / \mathrm{Al} \mathrm{LDH}$ as its constituent material and a vibration appears at a wave number of $1931 \mathrm{~cm}^{-1}$ which indicates the presence of $\mathrm{C}=\mathrm{O}$ vibrations from the supporting material in the form of hydrochar (Normah et al., 2021).

The adsorption-desorption isotherm pattern of each material is shown in Figure 5. Figure 5 shows the pattern of each material following a type IV isotherm pattern and a hysteresis loop type 3 where the adsorption-desorption patterns do not overlap and the pores are not uniform. The type IV isotherm pattern indicates a mesoporous material (Palapa et al., 2021). The nitrogen desorption adsorption pattern in Figure 5 produces the values of the surface area, pore volume, and pore diameter of each material as presented in Table 1.

Table 1 shows the basic material $\mathrm{Mg} / \mathrm{Al} \mathrm{LDH}$ has a surface area of $2.155 \mathrm{~m}^{2} / \mathrm{g}$, and the supporting material for humic acid and hydrochar is $2.750 \mathrm{~m}^{2} / \mathrm{g}$ and $22.635 \mathrm{~m}^{2} / \mathrm{g}$, respectively. The process of modifying layered double hydroxide into composites has succeeded in increasing the surface area of $\mathrm{Mg} / \mathrm{Al}$ LDH. The layered double hydroxide material composited with humic acid showed a surface area from $2.155 \mathrm{~m}^{2} / \mathrm{g}$ to 3.337 $\mathrm{m}^{2} / \mathrm{g}$. The layered double hydroxide material composited with hydrochar showed a larger surface area than the $\mathrm{Mg} / \mathrm{Al} \mathrm{LDH}$ base material. The surface area increased 37 times, from 2.155 $\mathrm{m}^{2} / \mathrm{g}$ to $74.207 \mathrm{~m}^{2} / \mathrm{g}$. Hydrochar using the hydrothermal carbonization method while humic acid does not, so the carbon that is still joined in the hydrochar is hydrolyzed so that the surface area of $\mathrm{Mg} / \mathrm{Al}-\mathrm{HC}$ is larger than that of $\mathrm{Mg} / \mathrm{Al}-\mathrm{AH}$.
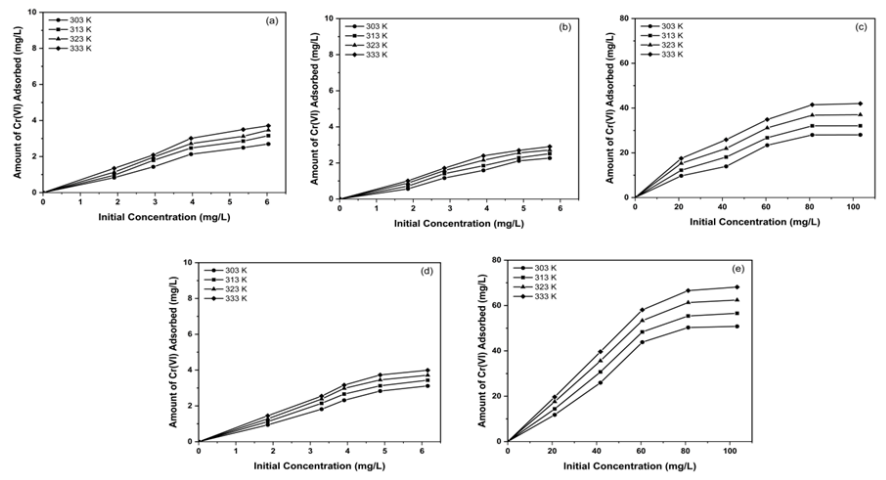

Figure 6. Effect of Adsorption Contact Time on $\mathrm{Mg} / \mathrm{Al} \mathrm{LDH}$ (a), $\mathrm{AH}$ (b), $\mathrm{HC}$ (c), $\mathrm{Mg} / \mathrm{Al}-\mathrm{AH}(\mathrm{d})$, and $\mathrm{Mg} / \mathrm{Al}-\mathrm{HC}$ (e)

Figure 6 shows that as the temperature increases, more $\mathrm{Cr}(\mathrm{VI})$ is adsorbed. The maximum adsorption process of 
Table 1. BET Analysis of Materials

\begin{tabular}{cccc}
\hline Adsorbent & $\begin{array}{c}\text { Surface Area } \\
\left(\mathrm{m}^{2} / \mathrm{g}\right)\end{array}$ & $\begin{array}{c}\text { Pore Volume } \\
\left(\mathrm{cm}^{2} / \mathrm{g}\right) \mathrm{BJH}\end{array}$ & $\begin{array}{c}\text { Pore Size } \\
(\mathrm{nm}), \mathrm{BJH}\end{array}$ \\
\hline $\mathrm{Mg} / \mathrm{Al} \mathrm{LDH}$ & 2.155 & 0.028 & 6.225 \\
$\mathrm{AH}$ & 2.75 & 0.028 & 6.223 \\
$\mathrm{HC}$ & 22.635 & 0.044 & 2.769 \\
$\mathrm{Mg} / \mathrm{Al}-\mathrm{AH}$ & 3.337 & 0.007 & 4.165 \\
$\mathrm{Mg} / \mathrm{Al}-\mathrm{HC}$ & 74.207 & 0.148 & 19.102 \\
\hline
\end{tabular}

Table 2. Isotherm Adsorption

\begin{tabular}{|c|c|c|c|c|c|c|}
\hline \multirow[b]{2}{*}{ Adsorbent } & \multirow{2}{*}{$\begin{array}{l}\text { Adsorption } \\
\text { Isotherm }\end{array}$} & \multirow{2}{*}{$\begin{array}{c}\text { Adsorption } \\
\text { Constant }\end{array}$} & \multicolumn{4}{|c|}{$\mathrm{T}(\mathrm{K})$} \\
\hline & & & 303 & 313 & 323 & 333 \\
\hline \multirow[t]{6}{*}{$\mathrm{MgAl} / \mathrm{LDH}$} & \multirow[t]{3}{*}{ Langmuir } & $Q_{\max }$ & 30.211 & 28.736 & 27.933 & 28.09 \\
\hline & & $\mathrm{K}_{L}$ & 0.074 & 0.113 & 0.191 & 0.279 \\
\hline & & $\mathrm{R}^{2}$ & 0.997 & 0.999 & 0.999 & 0.999 \\
\hline & \multirow[t]{3}{*}{ Freundlich } & $n$ & 0.624 & 0.748 & 0.431 & 0.81 \\
\hline & & $\mathrm{K}_{F}$ & 16.765 & 16.924 & 19.342 & 21.237 \\
\hline & & $\mathrm{R}^{2}$ & 0.931 & 0.981 & 0.953 & 0.993 \\
\hline \multirow[t]{6}{*}{$\mathrm{AH}$} & \multirow[t]{3}{*}{ Langmuir } & $Q_{\max }$ & 3.509 & 13.643 & 21.368 & 9.634 \\
\hline & & $\mathrm{K}_{L}$ & 0.126 & 0.053 & 0.055 & 0.172 \\
\hline & & $\mathrm{R}^{2}$ & 0.926 & 0.987 & 0.935 & 0.806 \\
\hline & \multirow[t]{3}{*}{ Freundlich } & $n$ & 0.718 & 0.882 & 0.845 & 0.93 \\
\hline & & $\mathrm{K}_{F}$ & 0.469 & 0.755 & 1.093 & 1.392 \\
\hline & & $\mathrm{R}^{2}$ & 0.825 & 0.855 & 0.941 & 0.999 \\
\hline \multirow[t]{6}{*}{$\mathrm{HC}$} & \multirow[t]{3}{*}{ Langmuir } & $\mathrm{Q}_{\max }$ & 34.364 & 45.662 & 46.083 & 48.78 \\
\hline & & $\mathrm{K}_{L}$ & 0.028 & 0.037 & 0.066 & 0.105 \\
\hline & & $\mathrm{R}^{2}$ & 0.977 & 0.94 & 0.967 & 0.982 \\
\hline & \multirow[t]{3}{*}{ Freundlich } & $n$ & 0.599 & 0.967 & 0.51 & 0.602 \\
\hline & & $\mathrm{K}_{F}$ & 2.086 & 4.024 & 7.463 & 11.256 \\
\hline & & $\mathrm{R}^{2}$ & 0.911 & 0.944 & 0.947 & 0.964 \\
\hline \multirow[t]{6}{*}{$\mathrm{Mg} / \mathrm{Al}-\mathrm{AH}$} & \multirow[t]{3}{*}{ Langmuir } & $\mathrm{Q}_{\max }$ & 32.017 & 9.804 & 6.969 & 6.072 \\
\hline & & $\mathrm{K}_{L}$ & 0.03 & 0.228 & 0.545 & 1.026 \\
\hline & & $\mathrm{R}^{2}$ & 0.91 & 0.951 & 0.941 & 0.95 \\
\hline & \multirow[t]{3}{*}{ Freundlich } & $n$ & 0.979 & 0.203 & 0.454 & 0.696 \\
\hline & & $\mathrm{K}_{F}$ & 1.196 & 1.781 & 2.404 & 2.998 \\
\hline & & $\mathrm{R}^{2}$ & 0.979 & 0.906 & 0.936 & 0.925 \\
\hline \multirow[t]{6}{*}{$\mathrm{Mg} / \mathrm{Al}-\mathrm{HC}$} & \multirow[t]{3}{*}{ Langmuir } & $Q_{\max }$ & 208.333 & 86.957 & 74.627 & 78.74 \\
\hline & & $\mathrm{K}_{L}$ & 0.007 & 0.048 & 0.149 & 0.469 \\
\hline & & $\mathrm{R}^{2}$ & 0.998 & 0.999 & 0.956 & 0.993 \\
\hline & \multirow[t]{3}{*}{ Freundlich } & $n$ & 0.836 & 0.537 & 0.471 & 0.27 \\
\hline & & $\mathrm{K}_{F}$ & 1.153 & 2.563 & 8.547 & 9.707 \\
\hline & & $\mathrm{R}^{2}$ & 0.986 & 0.951 & 0.926 & 0.802 \\
\hline
\end{tabular}

$\mathrm{Cr}(\mathrm{VI})$ occurs at a temperature of $333 \mathrm{~K}$.

The effect of adsorption isotherm and thermodynamics can be calculated through equation 5-8 according to (Siregar et al., 2021). The parameter $Q_{m}$ is a constant that indicates the adsorbed solute at equilibrium or indicates monolayer adsorption. $\mathrm{Q}_{m}$ is the maximum adsorption capacity of an adsorbent with units of $\mathrm{mg} / \mathrm{g}$. While $\mathrm{K}_{L}$ is a constant that shows the bond energy between the adsorbate and adsorbent $(\mathrm{L} / \mathrm{mg})$. The adsorption coefficient $\left(\mathrm{K}_{F}\right)$ can be used as an indicator of adsorption capacity and $1 / \mathrm{n}$ is the adsorption intensity. The higher the $\mathrm{K}_{F}$ value, the greater the adsorption capacity, $n$ is a measure of deviation from the linearity of adsorption which is generally used to determine the correctness of an adsorption. If the value of $n=1$ then the adsorption that occurs is linear. If 
Table 3. Thermodynamic Adsorption

\begin{tabular}{cccccc}
\hline \multirow{2}{*}{ Adsorbent } & $\mathrm{T}(\mathrm{K})$ & $\begin{array}{c}\mathrm{Qe} \\
(\mathrm{mg} / \mathrm{g})\end{array}$ & $\begin{array}{c}\Delta \mathrm{H} \\
(\mathrm{kJ} / \mathrm{mol})\end{array}$ & $\begin{array}{c}\Delta \mathrm{S} \\
(\mathrm{J} / \mathrm{mol} \mathrm{K})\end{array}$ & $\begin{array}{c}\Delta \mathrm{G} \\
(\mathrm{kJ} / \mathrm{mol})\end{array}$ \\
\hline $\mathrm{MgAl} / \mathrm{LDH}$ & 303 & 2.698 & 18.879 & 0.061 & 0.462 \\
& 313 & 3.157 & & & -0.146 \\
& 323 & 3.466 & & & -0.754 \\
& 333 & 3.708 & & & -1.362 \\
$\mathrm{AH}$ & 303 & 2.268 & 12.643 & 0.038 & 1.036 \\
& 313 & 2.512 & & & 0.653 \\
& 323 & 2.717 & & & 0.27 \\
& 333 & 2.907 & & & -0.113 \\
$\mathrm{HC}$ & 303 & 9.715 & 29.09 & 0.16 & 0.554 \\
& 313 & 12.244 & & & -1.048 \\
& 323 & 15.285 & & & -2.65 \\
$\mathrm{Mg} / \mathrm{Al}-\mathrm{AH}$ & 333 & 17.512 & & & -4.252 \\
& 303 & 3.114 & 16.423 & 0.054 & -0.059 \\
& 323 & 3.434 & & & -0.603 \\
$\mathrm{Mg} / \mathrm{Al}-\mathrm{HC}$ & 333 & 3.993 & & & -1.147 \\
& 303 & 50.311 & 28.811 & 0.099 & -1.691 \\
& 313 & 55.392 & & & -2.124 \\
& 323 & 61.327 & & & -3.1 \\
& 333 & 66.579 & & & -4.088 \\
\hline
\end{tabular}

the value of $n<1$ then the adsorption process is a chemical adsorption process, but if the value for $n>1$ then the adsorption is physical adsorption.

Changes in the concentration of adsorbate in the adsorption process can be studied through adsorption isotherms. The adsorption isotherms commonly used are Langmuir and Freundlich isotherms (Normah et al., 2021). Determination of the equilibrium model depends on the value of the determinant coefficient $\left(\mathrm{R}^{2}\right)$ close to 1 . The data in Table 2 shows that the adsorption process using $\mathrm{Mg} / \mathrm{Al} \mathrm{LDH}, \mathrm{AH}, \mathrm{HC}, \mathrm{Mg} / \mathrm{Al}-$ $\mathrm{AH}$, and $\mathrm{Mg} / \mathrm{Al}-\mathrm{HC}$ tends to follow the Langmuir equation seen from $\mathrm{R}^{2}$ value is closer to 1 . The Langmuir adsorption isotherm pattern indicates that the adsorption takes place only in one layer (monolayer) and the surface sites are homogeneous because each active site can only adsorb 1 molecule. Characteristics of chemical adsorption is that it occurs at high temperatures, the type of interaction is chemical interaction, and the process is irreversible. The maximum adsorption capacities of $\mathrm{Mg} / \mathrm{Al} \mathrm{LDH}, \mathrm{AH}, \mathrm{HC}, \mathrm{Mg} / \mathrm{Al}-\mathrm{AH}$, and $\mathrm{Mg} / \mathrm{Al}-\mathrm{HC}$ were $30.211 \mathrm{mg} / \mathrm{g}, 13.643 \mathrm{mg} / \mathrm{g}, 34.364 \mathrm{mg} / \mathrm{g}, 32.017 \mathrm{mg} / \mathrm{g}$, and $208.333 \mathrm{mg} / \mathrm{g}$ as shown in Table 2 . Based on the data obtained in Table 2, Mg/Al-AH and $\mathrm{Mg} / \mathrm{Al}-\mathrm{HC}$ have a greater adsorption capacity because the surface area is larger than the constituent material than the constituent materials so that they are more effectively used as adsorbents in the process of removing $\mathrm{Cr}(\mathrm{VI})$ metal from aqueous aqueous solutions.

Table 3 shows the effect of thermodynamics on adsorption. The determined thermodynamic parameters include enthalpy
$(\Delta \mathrm{H})$, entropy $(\Delta \mathrm{S})$, and gibbs free energy $(\Delta \mathrm{G})$ which are presented in Table 3 . The determination of the value of $\Delta \mathrm{H}$ in the $\mathrm{Cr}(\mathrm{VI})$ adsorption process was carried out to determine whether the adsorption process was endothermic or exothermic, as well as the tendency of physical and chemical adsorption processes through the $\Delta \mathrm{H}$ value. The determination of $\Delta \mathrm{S}$ was carried out to determine the mobility of the adsorbate during the adsorption process, while $\Delta \mathrm{G}$ was determined to determine the spontaneity of the adsorption process (Amin et al., 2020).

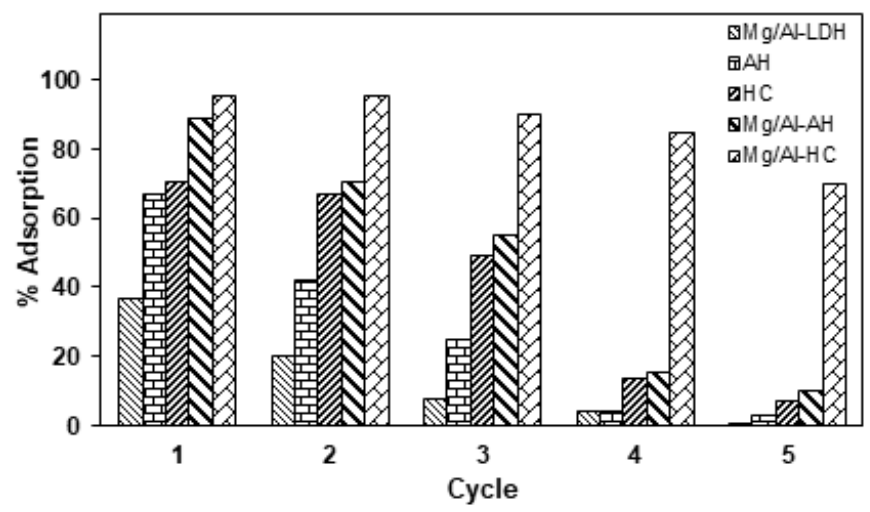

Figure 7. Regeneration of $\mathrm{Mg} / \mathrm{Al} \mathrm{LDH}, \mathrm{AH}, \mathrm{HC}, \mathrm{Mg} / \mathrm{Al}-\mathrm{AH}$, and $\mathrm{Mg} / \mathrm{Al}-\mathrm{HC}$

Table 3 shows the positive $\Delta \mathrm{H}$ values. Siregar et al. (2021) 
revealed that a positive value of $\Delta \mathrm{H}$ indicates that the adsorption process is endothermic, where the adsorbent and adsorbate require energy to interact with each other. The determination of $\Delta \mathrm{S}$ shows a small value indicating the degree of disorder during the adsorption process is small. The determination of the next thermodynamic parameter in the form of $\Delta \mathrm{G}$ is overall negative. This indicates that the adsorption process takes place spontaneously using little energy.

The regeneration process of $\mathrm{Mg} / \mathrm{Al}-\mathrm{AH}$, and $\mathrm{Mg} / \mathrm{Al}-\mathrm{HC}$ composites are presented in Figure 7 . Figure 7 shows the adsorption ability of $\mathrm{Mg} / \mathrm{Al}-\mathrm{AH}$ and $\mathrm{Mg} / \mathrm{Al}-\mathrm{HC}$ more stable than $\mathrm{Mg} / \mathrm{Al} \mathrm{LDH}, \mathrm{AH}$, and $\mathrm{HC}$ because $\mathrm{Mg} / \mathrm{Al}-\mathrm{AH}$ and $\mathrm{Mg} / \mathrm{Al}-$ $\mathrm{HC}$ are protected by supporting materials in the form of humic acid and hydrochar. The $\mathrm{Mg} / \mathrm{Al}-\mathrm{AH}$ composite showed the first adsorption ability of $89.064 \%$ and there was no significant decrease in the next cycle. The $\mathrm{Mg} / \mathrm{Al}-\mathrm{HC}$ composite showed adsorption ability in the first cycle which reached $97.079 \%$ in the first cycle, the ability to survive up to the fifth cycle with a final ability of $75.029 \%$.

\section{CONCLUSIONS}

The preparation of $\mathrm{Mg} / \mathrm{Al}$ composite with the supporting material in the form of humic acid and hydrochar has been successfully synthesized. This is evidenced from the results of the main characterization of XRD which shows the appearance of $\mathrm{LDH}$ peaks and the supporting material in the form of humic acid and hydrochar. The surface area of $\mathrm{Mg} / \mathrm{Al}-\mathrm{AH}$ and $\mathrm{Mg} / \mathrm{Al}-\mathrm{HC}$ is larger than the constituent materials, which are $3.337 \mathrm{~m}^{2} / \mathrm{g}$ and $74.207 \mathrm{~m}^{2} / \mathrm{g}$, respectively. The maximum adsorption capacity of $\mathrm{Mg} / \mathrm{Al}-\mathrm{AH}$ and $\mathrm{Mg} / \mathrm{Al}-\mathrm{HC}$ is also greater than that of $\mathrm{Mg} / \mathrm{Al} \mathrm{LDH}, \mathrm{AH}$, and HC. The adsorption capacity of $\mathrm{Mg} / \mathrm{Al}-\mathrm{AH}$ was $32.017 \mathrm{mg} / \mathrm{g}$ and the adsorption capacity of $\mathrm{Mg} / \mathrm{Al}-\mathrm{HC}$ was $208.333 \mathrm{mg} / \mathrm{g}$. The regeneration process is more effective using $\mathrm{Mg} / \mathrm{Al}-\mathrm{AH}$ and $\mathrm{Mg} / \mathrm{Al}-\mathrm{HC}$ as seen from the adsorption capacity which did not decrease significantly for five cycles.

\section{ACKNOWLEDGEMENT}

All authors thanks to the Laboratory of Inorganic Materials and Complexes of the Faculty of Mathematics and Natural Sciences, Sriwijaya University for support of this research.

\section{REFERENCES}

Ahmadpoor, F., S. A. Shojaosadati, and S. Z. Mousavi (2019). Magnetic Silica Coated Iron Carbide/Alginate Beads: Synthesis and Application for Adsorption of $\mathrm{Cu}$ (II) from Aqueous Solutions. International Journal of Biological Macromolecules, 128; 941-947

Amin, M., A. Alazba, and M. Shafiq (2020). LDH of NiZnFe and Its Composites with Carbon Nanotubes and Data Palm Biochar with Efficient Adsorption Capacity for RB5 Dye from Aqueous Solutions: Isotherm, Kinetic, and Thermodynamics Studies. Current Applied Physics, 2(1); 1-11
Bolbol, H., M. Fekri, and M. Hejazi-Mehrizi (2019). Layered Double Hydroxide Loaded Biochar as a Sorbent for The Removal of Aquatic Phosphorus: Behavior and Mechanism Insights. Arabian Journal of Geosciences, 12(16); 1-11

Chen, W., Y. Shen, Y. Ling, Y. Peng, M. Ge, and Z. Pan (2019). Synthesis of Positively Charged Polystyrene Microspheres for The Removal of Congo Red, Phosphate, and Chromium (VI). ACS Omega, 4(4); 6669-6676

Chen, Y. X., R. Zhu, Q. F. Ke, Y. S. Gao, C. Q. Zhang, and Y. P. Guo (2017). MgAl Layered Double Hydroxide/Chitosan Porous Scaffolds Loaded with PFT $\alpha$ to Promote Bone Regeneration. Nanoscale, 9(20); 6765-6776

El-Sherif, I., N. Fathy, A and A. Hanna (2013). Removal of Mn (II) and Fe (II) Ions from Aqueous Solution using Precipitation and Adsorption Methods. Journal of Applied Sciences Research, 9(1); 233-239

Gadekar, M. R. and M. M. Ahammed (2016). Coagulation/Flocculation Process for Dye Removal Using Water Treatment Residuals: Modelling Through Artificial Neural Networks. Desalination and Water Treatment, 57(55); 2639226400

Hasan, I., D. Bhatia, S. Walia, and P. Singh (2020). Removal of Malachite Green by Polyacrylamide-G-Chitosan $\gamma-\mathrm{Fe}_{2} \mathrm{O}_{3}$ Nanocomposite an Application of Central Composite Design. Groundwater for Sustainable Development, 11(4); 1-12

Hatami, H., A. Fotovat, and A. Halajnia (2018). Comparison of Adsorption and Desorption of Phosphate on Synthesized $\mathrm{Zn}-\mathrm{Al} \mathrm{LDH}$ by Two Methods in a Simulated Soil Solution. Applied Clay Science, 152; 333-341

Helal, A. A., G. Murad, and A. Helal (2011). Characterization of Different Humic Materials by Various Analytical Techniques. Arabian Journal of Chemistry, 4(1); 51-54

Hosseinzadeh, H. and S. Ramin (2018). Effective Removal of Copper from Aqueous Solutions by Modified Magnetic Chitosan/Graphene Oxide Nanocomposites. International Journal of Biological Macromolecules, 113; 859-868

Hu, H., S. Wageh, A. A. Al-Ghamdi, S. Yang, Z. Tian, B. Cheng, and W. Ho (2020). NiFe-LDH Nanosheet/Carbon Fiber Nanocomposite with Enhanced Anionic Dye Adsorption Performance. Applied Surface Science, 51 1; 145570

Huang, Z., T. Wang, M. Shen, Z. Huang, Y. Chong, and L. Cui (2019). Coagulation Treatment of Swine Wastewater by The Method of in situ Forming Layered Double Hydroxides and Sludge Recycling for Preparation of Biochar Composite Catalyst. Chemical Engineering Journal, 369; 784-792

Lee, S. Y., J. W. Choi, K. G. Song, K. Choi, Y. J. Lee, and K.W. Jung (2019). Adsorption and Mechanistic Study for Phosphate Removal by Rice Husk Derived Biochar Functionalized with $\mathrm{Mg} / \mathrm{Al}-$ Calcined Layered Double Hydroxides Via Co-Pyrolysis. Composites Part B: Engineering, 176; 107209

Li, S., Y. Yang, S. Huang, Z. He, C. Li, D. Li, B. Ke, C. Lai, and Q. Peng (2020a). Adsorption of Humic Acid from Aqueous Solution by Magnetic Zn/Al Calcined Layered Double Hydroxides. Applied Clay Science, 188(3); 1-10

Li, Z., H. Hanafy, L. Zhang, L. Sellaoui, M. S. Netto, M. L. 
Oliveira, M. K. Seliem, G. L. Dotto, A. Bonilla-Petriciolet, and Q. Li (2020b). Adsorption of Congo Red and Methylene Blue Dyes on an Ashitaba Waste and a Walnut Shell Based Activated Carbon from Aqueous Solutions: Experiments, Characterization and Physical Interpretations. Chemical Engineering Journal, 388; 124263

Mahjoubi, F. Zahra, A. Khalidi, A. Elhalil, R. Elmoubarki, O. Cherkaoui, S. Mhamed, and N. Barka (2017). Performance of $\mathrm{Zn}-, \mathrm{Mg}$ - and $\mathrm{Ni}-\mathrm{Al}$ Layered Double Hydroxides in Treating an Industrial Textile Wastewater. Journal of Applied Surfaces and Interfaces, 2(3); 1-11

Marques, B. S., K. Dalmagro, K. S. Moreira, M. L. Oliveira, S. L. Jahn, T. A. de Lima Burgo, and G. L. Dotto (2020). Ca$\mathrm{Al}, \mathrm{Ni}-\mathrm{Al}$ and $\mathrm{Zn}-\mathrm{Al} \mathrm{LDH}$ Powders as Efficient Materials to Treat Synthetic Effluents Containing o-nitrophenol. Journal of Alloys and Compounds, 838; 155628

Normah, N., N. Juleanti, P. M. S. B. N. Siregar, A. Wijaya, N. R. Palapa, T. Taher, and A. Lesbani (2021). Size Selectivity of Anionic and Cationic Dyes Using LDH Modified Adsorbent with Low-Cost Rambutan Peel to Hydrochar. Bulletin of Chemical Reaction Engineering $\mathcal{E}$ Catalysis, 16(4); 869-880

Palapa, N. R., T. Taher, P. M. S. B. N. Siregar, N. Normah, N. Juleanti, A. Wijaya, A. F. Badri, and A. Lesbani (2021). High Structural Stability and Adsorption Capacity of Zn/AlBiochar and $\mathrm{Cu} / \mathrm{Al}-$ Biochar Toward Adsorption of $\mathrm{Cr}(\mathrm{VI})$. Journal of Ecological Engineering, 22(4); 213-223

Rahmadan, J., V. Parhusip, N. R. Palapa, T. Taher, R. Mohadi, and A. Lesbani (2021). ZnAl-Humic Acid Composite as Adsorbent of Cadmium(II) from Aqueous Solution. Science and Technology Indonesia, 6(4); 247-255

Rahmanian, O., M. Dinari, and S. Neamati (2018). Synthesis and Characterization of Citrate Intercalated Layered Double Hydroxide as a Green Adsorbent for $\mathrm{Ni}^{2+}$ And $\mathrm{Pb}^{2+} \mathrm{Re}-$ moval. Environmental Science and Pollution Research, 25(36); 36267-36277

Saheed, I. O., O. W. Da, and F. B. M. Suah (2020). Chitosan Modifications for Adsorption of Pollutants. Journal of Hazardous Materials, 408; 124889

Shrestha, S. L. (2018). Study of the Adsorption Kinetics of Iron Ion from Wastewater Using Banana Peel. International Journal of Advanced Research Chemical Science, 5(3); 1-8

Siregar, P. M. S. B. N., N. R. Palapa, A. Wijaya, E. S. Fitri, and A. Lesbani (2021). Structural Stability of Ni/Al Layered Double Hydroxide Supported on Graphite and Biochar Toward Adsorption of Congo Red. Science and Technology Indonesia, 6(2); 85-95

Zhang, A., W. Chen, Z. Gu, Q. Li, and G. Shi (2018). Mechanism of Adsorption of Humic Acid by Modified Aged Refuse. RSC Advances, 8(59); 33642-33651

Zhang, L., F. He, W. Mao, and Y. Guan (2020). Fast and Efficient Removal of $\mathrm{Cr}(\mathrm{VI})$ to ppb Level Together with $\mathrm{Cr}$ (III) Sequestration in Water using Layered Double Hydroxide Interclated with Diethyldithiocarbamate. Science of The Total Environment, 727; 138701

Zhang, Y., J. Zhao, Z. Jiang, D. Shan, and Y. Lu (2014). Biosorption of Fe (II) and Mn (II) Ions from Aqueous Solution by Rice Husk Ash. Biomed Research International, 2; $1-10$

Zubair, M., I. Ihsanullah, H. A. Aziz, M. A. Ahmad, and M. A. Al-Harthi (2021). Sustainable Wastewater Treatment by Biochar/Layered Double Hydroxide Composites: Progress, Challenges, and Outlook. Bioresource Technology, 319; 124128 